\title{
5-AMINO-1,3,4-THIADIAZOLE-2-THIOL CORROSION CURRENT DENSITY AND ADSORPTION THERMODYNAMICS ON ASTM A-890-1B STAINLESS STEEL IN A 3.5\% NaCI SOLUTION
}

\author{
M. GUZMÁN*, R. LARA AND L. VERA \\ Departamento de Química, Facultad de Ciencias, Universidad Católica del Norte, Antofagasta-Chile \\ (Received: July 14, 2008 - Accepted: December 18, 2008)
}

\begin{abstract}
Using the electrochemical linear polarization resistance technique, 5-amino-1,3,4-thiadiazole-2-thiol corrosion current density on ASTM A-890-1B steel is determined in a $3.5 \% \mathrm{NaCl}$ solution at different temperatures. The corrosion inhibition process is mixed. Apparent activation energy is calculated, being the one with inhibitor slightly greater than that without it. Adsorption matches Damaskin-Parsons isotherm, showing that molecules adsorbed by the metal surface reject each other. Three water molecules on the metal surface are replaced by one inhibitor molecule. This is demonstrated by calculating the surface these molecules project. Normal thermodynamic adsorption parameters are calculated, showing that the process is spontaneous and exothermic. Inhibitor adsorption on the metal surface is a chemical adsorption.
\end{abstract}

Keywords: inhibitor corrosion, duplex stainless steel, potentiodynamic polarization, adsorption isotherm

\section{INTRODUCTION}

In general, some organic compounds have shown great effectiveness for inhibiting aqueous corrosion in a great variety of metals and alloys ${ }^{1,2}$. The adsorption of these metals is generally explained by the formation of a film on the metal surface. Inhibitor adsorption can prevent cathodic and anodic reactions or both together. This inhibition may be a chemical or physical adsorption. This effect is obtained through the formation of a diffusion barrier or by blocking reaction sites ${ }^{3,4}$. Electrostatic attraction between the charged inhibitor molecule and the active charged sites on the metal surface result in physical adsorption. The literature shows that most organic inhibitors are adsorbed on the metal by surface water molecule displacement, forming a compact barrier ${ }^{3}$.

Molecules containing nitrogen and sulfur in their structures are good inhibitors, as compared to compounds that only contain sulfur or nitrogen ${ }^{5}$.

The inhibition property of these compounds is attributed to their molecular structure. The planarity and pairs of free electrons in heteroatoms are important characteristics that determine the adsorption of these molecules on the metal surface $^{4}$. Heterocyclic compounds containing sulfur and nitrogen are good corrosion inhibitors in aggressive mediums $\mathrm{s}^{5,6,7,10}$

There are currently stainless steel alloys highly resistant to corrosion such as duplex stainless steels. This is the case of ASTM A-890-1B, the objective of this study. Duplex stainless steels have a chemical composition carefully adjusted to obtain a mixed crystalline structure of about half a ferritic phase and half an autenistic phase. This is possible due to the addition of ferritic steel and a small controlled amount of nickel (sometimes $\mathrm{Mn}$ and $\mathrm{N}$ ). The resulting alloy shows mechanical characteristics much better than those of autenistic steel, allowing the use of fewer thickness and thus saving material. In addition, good resistance to uniform and localized corrosion such as pitting, crevice or cracking is obtained. Very good results have been reported for some of the most critical cases such as high chloride concentration and the presence of reducing agents and hydrogen sulfide).

The 5-amino-1,3,4-thiadiazole-2-thiol organic compound has been frequently used as copper corrosion inhibitor ${ }^{11-14}$. This compound reacts with a variety of metallic ions, forming a thin complex polymeric layer on the metal surface, thus forming complexes. This compound contains nitrogen and sulfur atoms, that is, heteroatoms that result in metal adsorption.

The phenomenon of 5-amino-1,3,4-thiadiazole-2-thiol adsorption on an ASTM A-890-1B stainless steel surface in a $3.5 \% \mathrm{NaCl}$ solution was studied. Corrosion current density data were used and some thermodynamics parameters were calculated.

\section{EXPERIMENTAL}

Materials and methods
The stainless steel Duplex ASTM A-890-1B has the following compositions
in \%
\begin{tabular}{|c|c|c|c|c|c|c|c|c|c|c|}
\hline $\mathrm{C}$ & $\mathrm{N}$ & $\mathrm{Si}$ & $\mathrm{P}$ & $\mathrm{S}$ & $\mathrm{Cr}$ & $\mathrm{Mn}$ & $\mathrm{Fe}$ & $\mathrm{Ni}$ & $\mathrm{Cu}$ & $\mathrm{Mo}$ \\
\hline 0.04 & 0.15 & 1.0 & 0.04 & 0.04 & 25.0 & 1.0 & bal & 5.5 & 3.0 & 1.82 \\
\hline
\end{tabular}

Resistance of stainless steel to pitting and crevice corrosion is improved by chromium, molybdenum and nitrogen addition.

Figure 1 shows the 5-amino-1,3,4-thiadiazole-2-thiol inhibitor molecule structure (Aldrich 98\%).

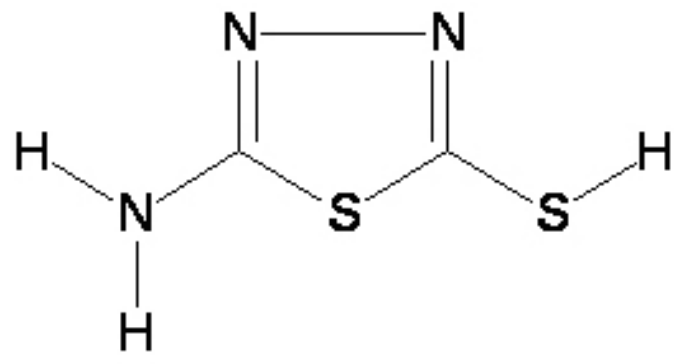

Figure 1.- 5-amino-1,3,4-thiadiazole-2-thiol structure.

Pretreatment. ASTM A-890-1B is annealed at $400^{\circ} \mathrm{C}$ for $2 \mathrm{~h}$ and then aircooled.

Electrodes. The working electrode was prepared on an ASTM A-890-1B pretreated cylinder connected to a copper conductor wire. The cylindrical part was isolated with epoxy resin, leaving a $0.21 \mathrm{~cm}^{2}$ exposed area. Before each experiment the exposed area of the working electrode was treated with soft $3 \mathrm{M}$ 1500 sand paper, to a metallic shine. Then it was brushed carefully, washed with distilled water, degreased with ethanol, and finally dried with soft paper.

The reference electrode was saturated calomel (SCE), which was cleaned before each experiment to avoid inhibitor contamination. It was externally cleaned with distilled water and dried with soft paper, keeping some $\mathrm{KCl}$ crystals inside. The auxiliary electrode was a platinum cylinder with a $1.77 \mathrm{~cm}^{2}$ exposed surface. Before each experiment it was cleaned with distilled water, degreased with ethanol, rinsed again with bi-distilled water, and dried with soft paper.

Working system. Fifty $\mathrm{mL}$ of $3.5 \% \mathrm{NaCl}$ electrolyte, with and without inhibitor, are introduced into the electrochemical cell and kept at constant temperature $\left(15,20,25,30,35\right.$ and $\left.40 \pm 0.5^{\circ} \mathrm{C}\right)$; the working electrode was kept inside the cell for $60 \mathrm{~min}$. Then the auxiliary electrode was introduced into the cell, facing (at the same height) the working electrode at 2-3 $\mathrm{mm}$ apart. The electrolyte was sucked into the Luggins' capillary and the reference electrode was put in place.

Potentiodynamic measures were taken after a 30 -min period of working electrode immersion into $3.5 \% \mathrm{NaCl}$ at different 5-amino-1,3,4-thiadiazole-2thiol concentrations $\left(5 \times 10^{-5} \mathrm{M} ; 10 \times 10^{-5} \mathrm{M} ; 20 \times 10^{-5} \mathrm{M} ; 30 \times 10^{-5} \mathrm{M} ; 50 \times\right.$ $\left.10^{-5} \mathrm{M}\right)$. The cell was connected to a Radiometer PGZ 301 Potentiostat, and the scanning speed was fixed at $60 \mathrm{mV} / \mathrm{s}$.

Possible orientation of 5-amino-1,3,4-thiadiazole-2-thiol on ASTM A-8901B stainless steel surface is analyzed, calculating areas and using Weblab ViewerPro 4.0 and $A C D /$ ChemSketch $10.02^{14}$. 


\section{RESULTS AND DISCUSSION}

Polarization curves

Figure 2 shows polarization curves at $25^{\circ} \mathrm{C}$.

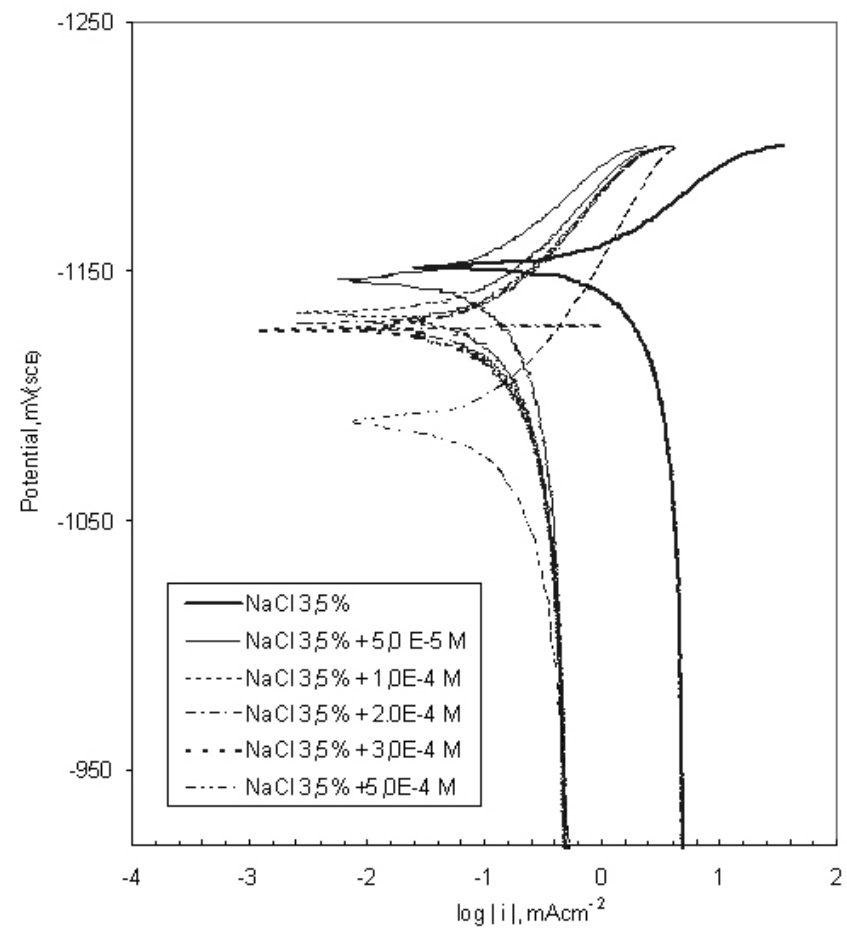

Figure 2.- Tafel-type curves at different inhibitor concentrations at $25^{\circ} \mathrm{C}$.

The results of polarization corrosion parameters as a function of inhibitor and temperature concentration are summarized in Table 1.

Table 1 shows that the greater the inhibitor concentration, the greater its efficiency, regardless of temperature. Inhibitor efficiency is given by

$$
I_{E}(\%)=\left(\frac{i_{C}-i_{C(i n h)}}{i_{C}}\right) \cdot 100
$$

where $\mathrm{i}_{\mathrm{c}}$ is corrosion current density without inhibitor and $\mathrm{i}_{\mathrm{c}(\text { (inh) }}$ is corrosion current density with inhibitor. The efficiency of a certain inhibitor concentration remains almost steady at different temperatures.

Maximum compound solubility is $5 \times 10^{-4}$ in a $3.5 \% \mathrm{NaCl}$ solution which, if greater, would allow a higher degree of covering. In the corrosion medium there may be competition between active ions such as $\mathrm{Cl}^{-}$and the inhibitor molecules due to adsorption on the metal surface. Adsorption will depend on the relative concentration of each of them. This means that the inhibitory effect of the organic molecules will depend on $\mathrm{Cl}^{-}$concentration, which decreases as the inhibitor capacity to form a protection layer on the metal surface increases. ${ }^{15}$

$\mathrm{E}_{\text {corr }}$ is almost steady. Regarding the curve without inhibitor, Tafel slopes change positively and negatively for the anodic and cathodic processes, respectively, that is, the inhibitor influences the two processes and behaves in a mixed fashion.
Table 1.- Potentiodynamic polarization parameters of 5-amino-1,3,4thiadiazole-2-thiol on ASTM A-890-1B stainless steel in an $\mathrm{NaCl} 3.5 \%$ aqueous solution.

\begin{tabular}{|c|c|c|c|c|c|}
\hline Concentration & $\mathrm{i}_{\text {corrosion }}$ & $\mathrm{I}_{\mathrm{E}}(\%)$ & $\mathrm{E}_{\text {corrosion }}$ & $\mathrm{b}_{\mathrm{a}}$ & $-b_{c}$ \\
\hline$\left(\mathrm{mol} / \mathrm{dm}^{3}\right) 10^{5}$ & $\begin{array}{l}(\mu \mathrm{A} / \\
\left.\mathrm{cm}^{2}\right)\end{array}$ & & $\begin{array}{l}\text { SCE } \\
(\mathrm{mV})\end{array}$ & $(\mathrm{mV} / \mathrm{dec})$ & $(\mathrm{mV} / \mathrm{dec})$ \\
\hline \multicolumn{6}{|c|}{$15^{\circ} \mathrm{C}$} \\
\hline 0 & 663 & - & -1162.7 & 51.80 & 33.50 \\
\hline 5 & 132 & 80.1 & -1133.6 & 108.9 & 57.70 \\
\hline 10 & 115 & 82.7 & -1114.0 & 113.9 & 65.10 \\
\hline 20 & 99.0 & 85.1 & -1122.0 & 100.0 & 60.30 \\
\hline 30 & 90.2 & 86.4 & -1115.1 & 46.00 & 53.20 \\
\hline 50 & 80.0 & 87.9 & -1161.0 & 87.30 & 33.00 \\
\hline \multicolumn{6}{|c|}{$20^{\circ} \mathrm{C}$} \\
\hline 0 & 713 & - & -1134.2 & 84.80 & 52.40 \\
\hline 5 & 142 & 80.1 & -1109.3 & 130.5 & 68.20 \\
\hline 10 & 124 & 82.6 & -1109.5 & 139.7 & 70.40 \\
\hline 20 & 106 & 85.1 & -1190.0 & 92.60 & 64.00 \\
\hline 30 & 97.0 & 86.4 & -1128.9 & 108.1 & 54.70 \\
\hline 50 & 85.9 & 88.0 & -1094.3 & 40.40 & 52.60 \\
\hline \multicolumn{6}{|c|}{$25^{\circ} \mathrm{C}$} \\
\hline 0 & 760 & - & -1153.2 & 67.10 & 36.90 \\
\hline 5 & 153 & 79.9 & -1110.2 & 152.0 & 69.20 \\
\hline 10 & 132 & 82.6 & -1097.5 & 144.3 & 72.30 \\
\hline 20 & 113 & 85.1 & -1104.8 & 143.4 & 70.20 \\
\hline 30 & 104 & 86.4 & -1095.0 & 96.30 & 67.60 \\
\hline 50 & 93.0 & 87.8 & -1148.1 & 84.10 & 42.60 \\
\hline \multicolumn{6}{|c|}{$30^{\circ} \mathrm{C}$} \\
\hline 0 & 810 & - & -1119.9 & 133.3 & 63.10 \\
\hline 5 & 165 & 79.6 & -1084.8 & 165.7 & 80.10 \\
\hline 10 & 141 & 82.6 & $\begin{array}{l}-1080.9 \\
\end{array}$ & 148.1 & 75.10 \\
\hline 20 & 122 & 84.9 & -1078.6 & 129.3 & 75.20 \\
\hline 30 & 112 & 86.2 & -1083.9 & 134.9 & 73.00 \\
\hline 50 & 100 & 87.7 & -1122.9 & 135.1 & 57.20 \\
\hline \multicolumn{6}{|c|}{$35^{\circ} \mathrm{C}$} \\
\hline 0 & 867 & - & -1134.1 & 95.50 & 63.40 \\
\hline 5 & 176 & 79.7 & -1084.0 & 155.0 & 78.40 \\
\hline 10 & 152 & 82.5 & -1069.4 & 93.70 & 77.30 \\
\hline 20 & 129 & 85.1 & -1074.0 & 136.7 & 74.40 \\
\hline 30 & 119 & 86.3 & -1070.1 & 92.90 & 73.70 \\
\hline 50 & 106 & 87.8 & -1066.2 & 99.80 & 71.90 \\
\hline \multicolumn{6}{|c|}{$40 \mathrm{C}$} \\
\hline 0 & 923 & - & -1093.2 & 155.6 & 84.70 \\
\hline 5 & 187 & 79.8 & -1120.1 & 99.20 & 57.90 \\
\hline 10 & 164 & 82.2 & -1084.5 & 182.5 & 84.70 \\
\hline 20 & 141 & 84.7 & -1059.5 & 149.7 & 83.60 \\
\hline 30 & 128 & 86.1 & -1070.5 & 135.8 & 77.60 \\
\hline 50 & 113 & 87.7 & -1045.3 & 81.50 & 60.20 \\
\hline
\end{tabular}

\section{Temperature effect}

Greater temperature increases corrosion density. The activation parameters of the corrosion process can be calculated from an Arrenhius-type equation:

$$
\mathrm{i}_{\mathrm{C}}=\mathrm{k} \exp -\frac{\mathrm{E}_{\mathrm{a}}}{\mathrm{RT}}
$$


Where $\mathrm{E}_{\mathrm{a}}$ is apparent corrosion activation energy; $\mathrm{k}$ is a pre-exponential Arrenhius factor; and $\mathrm{T}$ is absolute temperature. Using data in Table 1, the activation energy with and without inhibitor can be calculated. For example, the graph in Figure 3 is obtained by using $5.010^{-5} \mathrm{M}$ inhibitor concentration and plotting $\ln i_{c}$ against inverse absolute temperature,

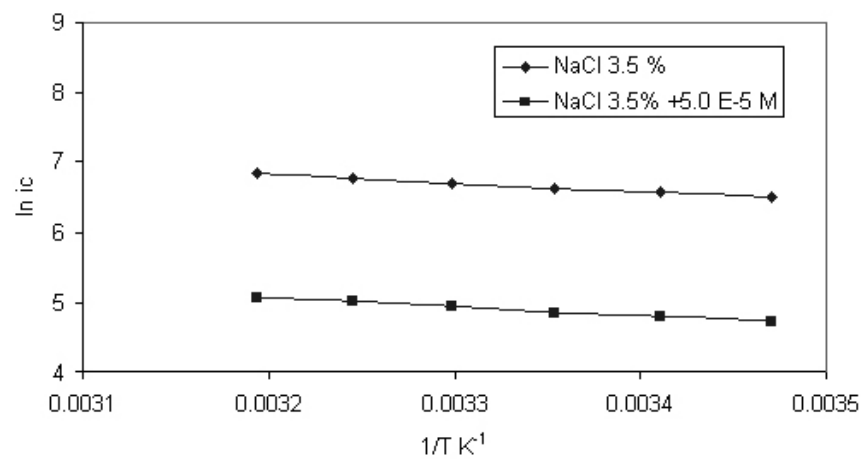

Figure 3.- Arrenhius-type graph with $5.010^{-5} \mathrm{M}$ and without inhibitor

The graph above shows two lines, one with inhibitor and another without it. Their correlation coefficient is close to -1 . The activation energy can be calculated from the slopes, $10.51 \mathrm{~kJ} / \mathrm{mol}$ with inhibitor being slightly higher than $9.88 \mathrm{~kJ} / \mathrm{mol}$ without inhibitor. This is in agreement with corrosion current density being lower in a system with inhibitor, This also occurs at other concentrations.

Adsorption isotherm

An adsorption isotherm describes the equilibrium between the concentration of a certain species in the phase in which it is present and in the metal-electrolyte phase. So, adsorption equilibrium can be written as

$$
\mathrm{ORG}_{\text {(aq) }}+\chi \mathrm{H}_{2} \mathrm{O}_{\text {(ads) }} \rightarrow \mathrm{ORG}_{(\text {ads) }}+\chi \mathrm{H}_{2} \mathrm{O}_{\text {(aq) }}
$$

where $O R G$ is the organic compound adsorbed and deadsorbed at the same speed on the metal surface. The adsorption phenomenon occurs in an aqueous solution containing the organic compound [ORG(aq)]. This involves the displacement of a certain number of water molecules $(\chi)$ by the organic compound which is adsorbed on the electrode surface $\left[\mathrm{H}_{2} \mathrm{O}(\mathrm{ads})\right]$.

Inhibitor efficiency $\left(\mathrm{I}_{\mathrm{E}}\right)$ is proportional to the degree of inhibitor lining $(\theta)$ on the surface of the steel that can have values from 0 to 1 . This degree of lining as a function of steady temperature concentration allows searching the isotherm that best matches experimental data. Tested isotherms are shown in Table 2.
Table 2.- Tested adsorption isotherms

\begin{tabular}{|c|c|}
\hline Isotherms & Equations \\
\hline Langmuir $^{15}$ & $\mathrm{bc}=\frac{\theta}{1-\theta}$ \\
\hline Langmuir multisitio $^{16}$ & $\mathrm{~b} c \mathrm{c}=\frac{\theta}{(1-\theta)^{\mathrm{n}}}$ \\
\hline Frumkin $^{17}$ & $b c=\left(\frac{\theta}{1-\theta}\right) \exp (-f \theta)$ \\
\hline Hill-de Boer ${ }^{18,19}$ & $b c=\left(\frac{\theta}{1-\theta}\right) \exp \left(\frac{\theta}{1-\theta}\right) \exp (-f \theta)$ \\
\hline Parsons $^{20}$ & $b c=\left(\frac{\theta}{1-\theta}\right) \exp \left(\frac{2-\theta}{(1-\theta)^{2}}\right) \exp (-f \theta)$ \\
\hline Damaskin-Parsons ${ }^{21}$ & $b c=\frac{\theta}{(1-\theta)^{\chi}} \exp (-f \theta)$ \\
\hline Kastening-Holleck ${ }^{22}$ & $\mathrm{~b} c=\frac{\theta}{\chi(1-\theta)^{\chi}}\left(1-\theta+\frac{\theta}{\chi}\right)^{(\chi-1)} \exp (-\mathrm{f} \theta)$ \\
\hline Flory-Huggins ${ }^{21}$ & $\mathrm{bc}=\frac{\theta}{\chi(1-\theta)^{\chi}}$ \\
\hline Dhar-Flory-Huggins ${ }^{21,23}$ & $b c=\frac{\theta}{(1-\theta)^{\chi} \exp (\chi-1)}$ \\
\hline 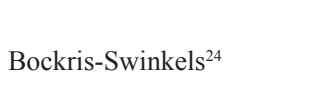 & $\mathrm{bc}=\frac{\theta}{(1-\theta)^{\chi}} \frac{[\theta+\chi(1-\theta)]^{(\chi-1)}}{\chi^{\mathrm{x}}}$ \\
\hline Langmuir-Freundlich ${ }^{25,26,27}$ & $b c=\left[\frac{\theta}{(1-\theta)}\right]^{\frac{1}{h}}$ \\
\hline Temkin $^{28}$ & $b c=\theta \exp (-f \theta)$ \\
\hline Toth $^{29}$ & $b c=\theta(1+[b])^{1}$ \\
\hline
\end{tabular}

where $\mathbf{b}$ is an adsorption equilibrium constant; $\mathbf{n}$ is the number of sites occupied by a molecule of the metal surface; $\mathbf{f}$ represents interactions among adsorbed molecules (this interaction parameter may be positive or negative: $f$ $<0$ indicates repulsion force and $\mathrm{f}>0$ shows lateral attraction among adsorbed 
organic molecules); $\chi$ is the substitution of water molecules by an inhibitor molecule; and $\mathbf{h}$ is a measure of adsorption energy distribution in different sites of the surface (this is a heterogeneity parameter $(0<\mathrm{h}<1)^{30-37)}$ ).

Adsorption isotherms that match experimental data are Damaskin-Parsons and Kastening-Holleck equations requiring the calculation of three parameters: $b, f$ and $\chi$.

The usual procedure to find the optimum value of these parameters is based on the minimization of the function objective ${ }^{14}$ (FO) defined by:

$$
F O=\sum_{i=1}^{p} \frac{1}{\left(c_{\exp _{i}}\right)^{2}}\left[C_{\exp _{i}}-C_{\text {calc }_{i}}(b, f, \chi)\right]^{2} \quad \text { (eq 4) }
$$

where $\mathbf{C}_{\text {cal }}$ is concentrated calculation and $\mathbf{C}_{\text {exp }}$ is experimental concentration. Subscript $i$ is a value in a set of $p$ inhibitor concentrations.

Criteria to determine which isotherms better match experimental data are: correlation coefficient, FO function, and intercept presence or absence in the isotherm equation. These criteria were tested for all isotherms, the one most in agreement being Damaskin -Parsons, whose value, $\chi=3$, is shown in Figures 4 and 5.

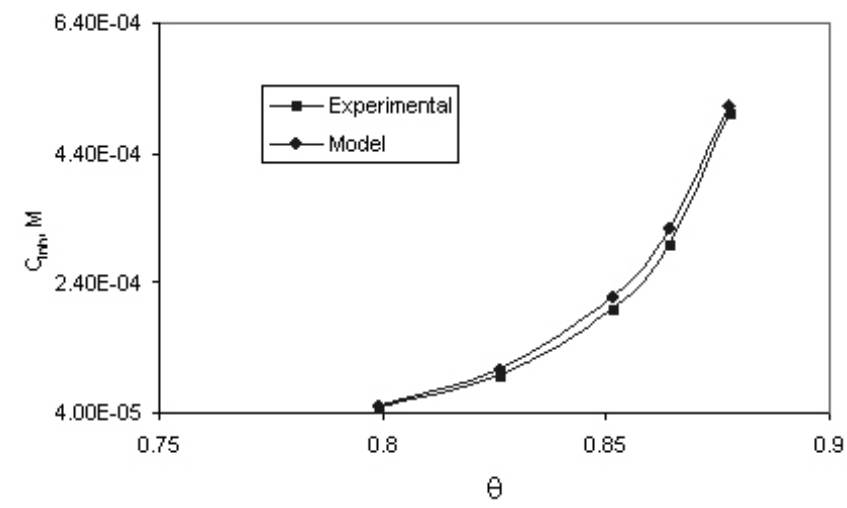

Figure 4.- Graph comparing experimental information and mathematical model using function objective (FO) $\chi=3$

Figure 5 is obtained by plotting Damaskin - Parsons isotherm linearly with

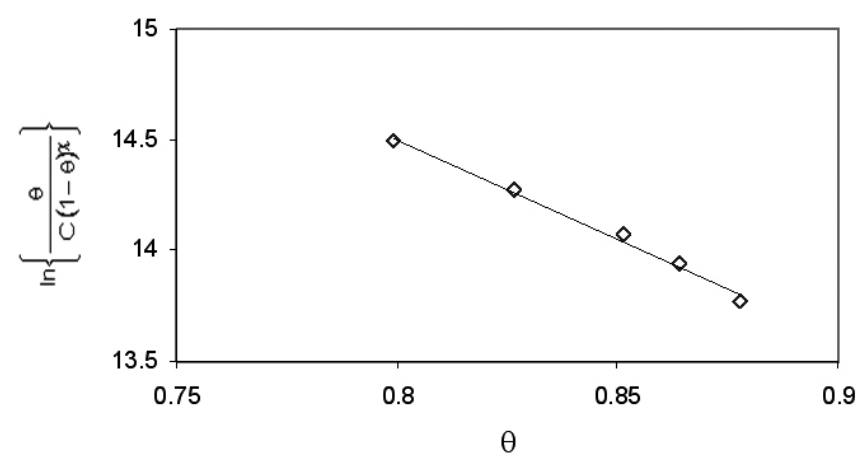

Figure 5.- Damaskin Parsons isotherm with $\chi=3$ at $25^{\circ} \mathrm{C}$.

The interaction among inhibitor molecules on the steel surface was obtained from the linear equation slope, in, $\left\{\frac{\theta}{C(1-\theta)^{x}}\right\}=-8.96 \theta+21.7$ whose

result was $f=-8.96$, with correlation coefficient $=0.991$. The negative value $f$ indicates that these are repulsion interactions.

Corrosion inhibitor adsorption in aqueous solution of the metal surface can be considered equivalent to an equilibrium reaction as shown in eq 3 , where $\chi$ water molecules adsorbed on the metal or alloy surface are displaced by an organic molecule. This equilibrium can be a function of free normal energy variation.
$K^{0}=\frac{\mathrm{H}_{2} \mathrm{O}_{\text {solution }}|| \text { Organic }_{\text {adsorbed-surface }} \mid}{\mid \mathrm{H}_{2} \mathrm{O}_{\text {adsorbed }} \text {-surface }|| \text { Organic }_{\text {solution }} \mid}=e^{-\frac{\Delta G_{\text {ads }}^{0}}{R T}}$, ordering the terms we have that $\frac{\mid \text { Organic }}{\text { adsorbed-surface } \mid}=\frac{\mid \text { Organic }_{\text {solution }} \mid}{\left|\mathrm{H}_{2} \mathrm{O}_{\text {Organic-surface }}\right|} e^{-\frac{\Delta \mathrm{G}_{\text {ads }}^{0}}{\mathrm{RT}}}$. If $\theta_{\text {organic }}$ is the degree of surface lining with organic molecules, then the first expression of the equation above is equal to the ratio

$$
\begin{aligned}
& \frac{\theta_{\text {organic }}}{1-\theta_{\text {organic }}}=\frac{\mid \text { Organic }}{\left|H_{2} \mathrm{O}_{\text {solution }}\right|} e^{-\frac{\Delta G_{\text {ads }}^{0}}{R T}} \text {. From the different isotherms, adsorption } \\
& \text { constants } b\left(\mathrm{dm}^{3} / \mathrm{mol}\right) \text { are equal to } b=\frac{1}{\left|\mathrm{H}_{2} \mathrm{O}_{\text {solución }}\right|} e^{-\frac{\Delta G_{\text {ads }}^{0}}{R T}} \text {. }
\end{aligned}
$$

At room temperature, water concentration is approximately $55.5 \mathrm{~mol} / \mathrm{dm}^{3}$. Then, normal adsorption energy variation could be determined by the relationship

$$
\Delta \mathrm{G}_{\mathrm{ads}}^{\mathrm{o}}=-\mathrm{R} \mathrm{T} \ln (\mathrm{b} 55.5) \quad(\text { eq } 5)
$$

In the linear equation, the intercept represents $\ln \mathbf{b}$. In this case $b=2.54$ $10^{9}\left(\mathrm{dm}^{3} / \mathrm{mol}\right)$. Thus, free adsorption energy at $25^{\circ} \mathrm{C}$ is $-63.3 \mathrm{~kJ} / \mathrm{mol}$. 3.

Free adsorption energy values for other temperatures are shown in Table

Table 3.- Adsorption equilibrium constant variation and $\Delta \mathrm{G}_{\mathrm{ads}}$ as a function of temperature.

\begin{tabular}{|c|c|c|}
\hline Temperature $\mathrm{C}$ & $\mathrm{b}\left(\mathrm{dm}^{3} / \mathrm{mol}\right)$ & $\Delta \mathrm{G}_{\text {ads }}(\mathrm{kJ} / \mathrm{mol})$ \\
\hline 15 & $2.6610^{9}$ & -61.6 \\
\hline 20 & $2.3110^{9}$ & -62.3 \\
\hline 25 & $2.5410^{9}$ & -63.7 \\
\hline 30 & $2.1610^{9}$ & -64.3 \\
\hline 35 & $1.4810^{9}$ & -64.4 \\
\hline 40 & $2.1810^{9}$ & -66.4 \\
\hline
\end{tabular}

A polynomial, $\Delta G_{\text {ads }}^{\circ}=-9.9210^{5}+1.3310^{4} \mathrm{~T}-66.4 \mathrm{~T}^{2}+1.4810^{-1} \mathrm{~T}^{3}-1.2310^{-4} \mathrm{~T}^{4}$. is obtained in correlating $\Delta G_{\text {ads }}^{\circ}$ : and absolute temperature, the correlation coefficient being -1 , as seen in Figure 6.

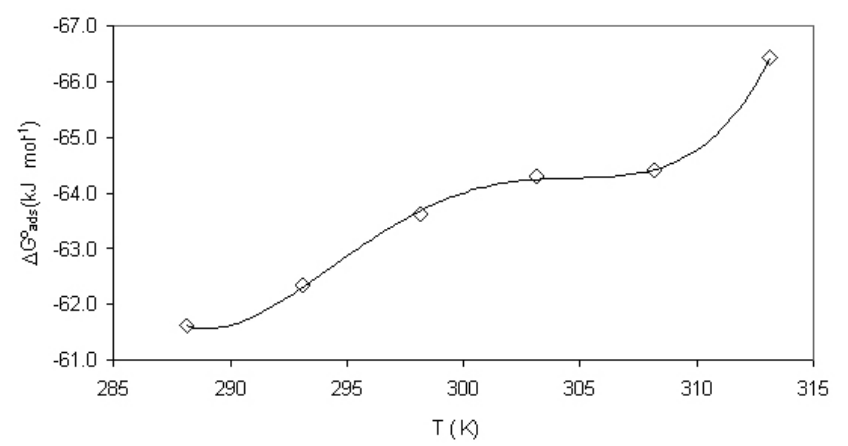

Figure 6.- Variation of $\Delta \mathrm{G}^{\mathrm{o}}$ ads versus T on ASTM A-890-1B stainless steel in a $3.5 \% \mathrm{NaCl}$ solution in the presence of 5-amino-1,3,4-thiadiazole-2-thiol. 
As $\left(\frac{\partial \Delta G_{\text {ads }}^{\circ}}{\partial T}\right)_{P}=-\Delta S_{\text {ads }}^{\circ}$ is normal adsorption entropy, then.

$\Delta S_{\text {ads }}^{\circ}=-1.3310^{4}+133 \mathrm{~T}-4.4310^{-1} \mathrm{~T}^{2}+4.9310^{-4} \mathrm{~T}^{3}$

Considering that, $\quad \Delta \mathrm{H}_{\text {ads }}^{\circ}=\Delta \mathrm{G}_{\text {ads }}^{\circ}+\mathrm{T} \Delta \mathrm{S}_{\text {ads }}^{\circ}$, we have that

$\Delta H_{\text {ads }}^{o}=-1.0110^{6}+13.410^{3} \mathrm{~T}-66.8 \mathrm{~T}^{2}+1.4810^{-1} \mathrm{~T}^{3}-1.2310^{-4} \mathrm{~T}^{4}$

At $25^{\circ} \mathrm{C}, \Delta G_{a d s}^{\mathrm{o}}=-63.6 \mathrm{~kJ} / \mathrm{mol} ;-0.73 \mathrm{~kJ} / \mathrm{mol} ; 210 \mathrm{~J} / \mathrm{mol} \mathrm{K}$. This means that the adsorption process is spontaneous and exothermic.

Negative values of $\Delta \mathrm{G}^{\mathrm{o}}$ suggest that inhibitor molecule adsorption on the steel surface is a spontaneous process. Generally, $\Delta \mathrm{G}^{\mathrm{o}}$ values up to $-20 \mathrm{~kJ} \mathrm{~mol}^{-1}$ are compatible with the electrostatic interaction between the charged molecules and charged metal (physical adsorption), while those more negative than $-40 \mathrm{~kJ}$ $\mathrm{mol}^{-1}$ involve charged pairs or organic molecule transfer onto the metal surface, so as to form a type of coordinated bond (chemical adsorption) s,38,39 $^{5}$.

When an adsorption process is endothermic $\left(\Delta \mathrm{H}^{\circ}>0\right)$ it is attributed to a chemical adsorption process, while an exothermic process $\left(\Delta \mathrm{H}^{\circ}<0\right)$ may imply either chemical or physical adsorption or a mixture of both ${ }^{5,38}$. In this case, the adsorption is exothermic.

Since the $\Delta \mathrm{S}^{\mathrm{o}}$ sign is positive, it opposes to what should be expected for exothermic process adsorption since it is always accompanied by entropy decrease. Ateya et al. ${ }^{33)}$ described this situation as organic compound adsorption accompanied by water molecule desorption from the surface. Thus, the adsorption process is thought to be exothermic and associated with solute entropy, as opposed to the solvent. Entropy gain accompanied by the adsorption process is attributed to solvent entropy increase ${ }^{42,43,44}$. Positive values of $\Delta \mathrm{S}^{\circ}$ show that the adsorption process is accompanied by entropy decrease, which is influenced by inhibitor adsorption on the metal surface ${ }^{5,45,46,47}$.

Possible mechanisms for chemical adsorption may be attributed to $\pi$ donating electrons of aromatic rings. ${ }^{5,38,42}$

Figures 7 and 8 , shows the horizontal and vertical molecules on the steel surface. Surface calculations ${ }^{14}$ that project these molecules on the metal surface indicate that the horizontal molecule has an about $0.52 \mathrm{~nm}^{2}$ surface and the vertical one, $0.33 \mathrm{~nm}^{2}$. On the other hand, the surface projecting the water molecule is $0.10 \mathrm{~nm}^{2}$ vertically and $0.13 \mathrm{~nm}^{2}$ horizontally. Since the inhibitor molecule adheres to the steel surface through the $\pi$ bonds of heteroatoms $\mathrm{N}$ and S, the molecule could be vertical. Then three water molecules could be displaced by each inhibitor molecule, in agreement with Damaskin-Parsons isotherm calculation.

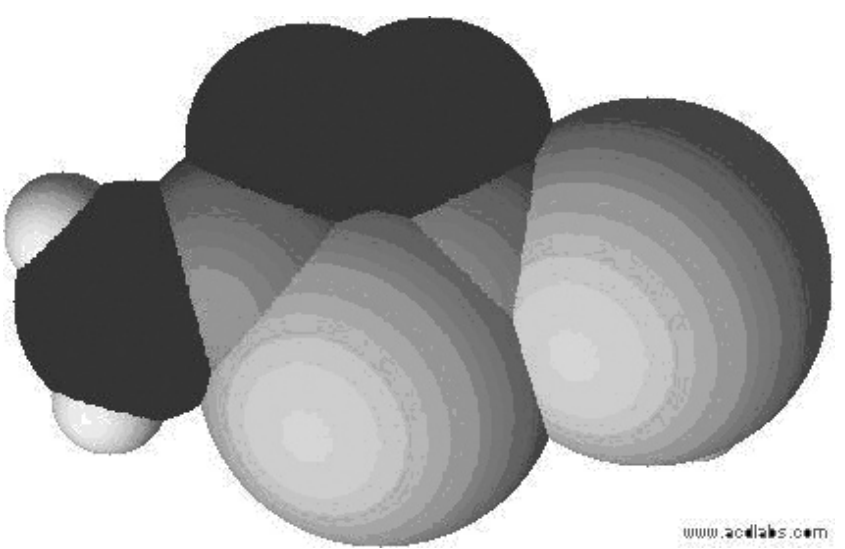

Figure 7.- 5-amino-1,3,4-thiadiazole-2-thiol horizontal molecule.

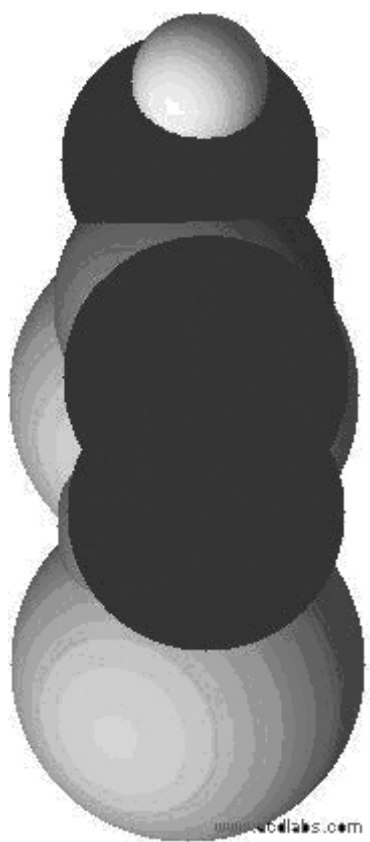

Figure 8.- 5-amino-1,3,4-thiadiazole-2-thiol vertical molecule.

\section{CONCLUSIONS}

5-amino-1,3,4-thiadiazole-2-thiol is a corrosion inhibitor of ASTM A-890$1 \mathrm{~B}$ steel in an $\mathrm{NaCl} 3.5 \%$ solution.

Inhibitor efficiency at any temperature increases as concentration increases.

Activation energy with inhibitor is slightly higher than that without it.

5-amino-1,3,4-thiadiazole-2-thiol affects the anodic and cathodic processes, thus showing that the inhibition mechanism is mixed.

5-amino-1,3,4-thiadiazole-2-thiol adsorption on ASTM A-890-1B steel surface obeys Damaskin-Parsons isotherm.

According to Damaskin-Parsons isotherm, 3 water molecules are displaced, as proven by surface calculation.

According to free energy variation signs and normal enthalpy, the adsorption process is spontaneous and exothermic.

The variation of the normal entropy process is positive, showing the formation of a chemically adsorbed inhibitor film on the metal.

Inhibitor molecules on the alloy surface reject each other.

\section{ACKNOWLEDGEMENTS}

The authors of this work thank UCN Magister Program in Chemical Sciences at Universidad Católica del Norte for its economic contribution. They also thank the Conicyt scholarship for the master candidate B.A..Roylester Lara. 


\section{REFERENCES}

1. V.S. Sastri. "Corrosion Inhibitors-Principles and Applications", John Wiley and Sons, Chichester,1998.

2. V.S. Sastri, J.R Perumareddi, Corrosion, 53, 617,(1997)

3. M.Elayyachy, A.El Idrissi, B.Hammouti, Corrosion Science, 48, 2470 , (2006)

4. Abd-El-Nabey, E.Khamis, M.Sh. Radaman, A.El-Gindy, Corrosion, 52, $671,(2000)$

5. F.Bentiss, M. Lebrini , M.Lagrenée, Corrosion Science, 47, 2915, (2005)

6. M.Abdallah, E.A. Helal, A.S. Fouda, Corrosion Science, 48, 1639, (2006)

7. H.Baeza, M. Guzman, P.Ortega, L. Vera, J. Chil. Chem. Soc., 48, 23, (2003)

8. L.Wang, G. J.Yin, Q-F Zhang, J.X .Pu, Corrosion, 56, 1083,(2000)

9. Abd-El-Nabey, E.Khamis, M.Sh. Radaman, A.El-Gindy, Corrosion, 52, $671,(2000)$

10. R.Gasparac, C. Martin, Journal of The Electrochemical Society, 148(4), B138- B145.(2001)

11. M.M.Antonijevic and M.B. Petrovic, Int. J. Electrochem. Sci., 3 $1,(2008)$

12. A. Lalitha, S. Ramesh, S. Rajeswari, Electrochemica Acta, 51, 47, (2005)

13. P. Ortega-Luoni, L. Vera, M. Guzman and P. Ortega-Lopez, J. Chil. Chem. Soc., 52, 1120, (2007).

14. J.M. Bastidas, P. Pinilla, J.L.Polo, and E. Cano, Corrosion, $\mathbf{5 8 , 9 2 2 , ( 2 0 0 2 )}$

15. S.S. Mahmoud, M.M. Ahmed, Portugalie Electrochimica Acta, 24, 37(2006))

16. I. Langmuir, J. Am. Chem. Soc., 40, 1361(1918)

17. T. Nitta, Huagong Xuebao, J. Am. Chem. Soc.,17, 39(1984)

18. A.N. Frumkin, Z. Phys. Chem., 116, 466(1925)

19. T.L. Hill, J. Chem. Phys., 20, 141(1952)

20. J.H. Boer, The Dinamical Character of Adsorption(Oxford,U.K.: Oxford University Press, 1953), p. 1-110

21. R. Parsons, J. Electroanal. Chem., 8,93(1964)

22. B.B. Damaskin, O.A. Petrii, V.V. Batrakov, Adsorption of Organic Compounds on Electrodes(New York, NY: Plenum Press, 1971), p. $86,94,247$

23. B. Kastening, L. Holleck, Talanta 12, 1 (1965)

24. H. P. Dhar, B. E. Conway, and K.M. Joshi, Electrochim. Acta,18,789 (1973)
25. J. O'M Bockris, D. A. J. Swinkels, J. Electrochem. Soc. ,111, 736(1964)

26. H. Freundlich, Colloid and Capillary Chemistry, Methuen, London (1926)

27. R. Sips, J.Chem.Phys. 16, 490(1948)

28. R. A. Koble and T. E. Corrigan, Ind. Eng. Chem., 44, 387(1952)

29. S.P. Cardoso and others, Ouim. Nova, 28,756(2005)

30. J.Toth, Surfactant Science Series. Adsorption, Theory, Modeling and Analysis.,CRC Press, New York,Vol. 107,pp. 301 (2002)

31. P. Kern and D. Landolt, Journal of The Electrochemical Society., 148(6),B228- B235(2001)

32. E. Gileadi,B.T. Rubin, and J.OM. Bockris, J. Phys. Chem.,69,3335 (1965)

33. W. Heiland,E. Gileadi, and J. O Bockris, J. Phys. Chem.,70, 1207 (1966)

34. B. G. Ateya, B. E. El-Anadouli, and F. M. El-Nizamy, Corros. Sci., 24,509(1984)

35. A.A. El-Awady,B.A. Abd-El-Nabey, and S.G. Aziz, J. Electrochem. Soc., 139, 2149(1992)

36. G.S. Jha, D. Prasad, and B.P.Chaudhry, J. Indian Chem. Soc., 77, 166(2000)

37. B. I. Ita and O. E. Offiong, Mater. Chem . Phys., 59, 179 (1999)

38. C. Das, Indian J. Chem. Technol.,3, 259(1996)

39. F.M. Donahue,K. Nobe, J. Electrochem. Soc., 112, 886 (1965)

40. E. Kamis, F. Bellucci, R. M: Latanission, E. S. H. El-Ashry, Corrosion, 47, $677(1991)$

41. S.A. Ali,*, A.M. El-Shareef, R.F. Al-Ghamdi, M.T. Saeed ,Corros. Sci., 47, 2659(2005)

42. M. Bouklah , B. Hammouti , M. Lagrenée , F. Bentiss, Corros. Sci., 48, 2831(2006)

43. Xianghong Li, Shuduan Deng, Guannan Mu, Hui Fu, Fazhong Yang, Corros. Sci., 50, 420(2008)

44. E. Kamis, F. Bellucci, R.M. Latanision, E.S.H. El-Ashry, Corrosion, 47, 677(1991)

45. Emranuzzaman, T. Kumar, S. Vishwanatham, G. Udayabhanu, Corros. Eng. Sci. Technol. 39, 327(2004).

46. G.N. Mu, X.H. Li, Q. Qu, J. Zhou, Acta Chim. Sinica, 62 , 2386(2004) (in Chinese).

47. Y.Y. Chen, X.D. Geng, Chem. J. Chin. Univ., 14, 1432(1993) (in Chinese).

48. M.Z.A. Rafiquee, S. Khan Portugalie Electrochimica Acta , 25, 419(2007). 